\title{
Habitat diversity analysis along an altitudinal sequence of alpine habitats: the Carabid beetle assemblages as a study model
}

\author{
ROBERTO PIZZOLOTTO*1 \\ ALICE ALBERTINI ${ }^{2}$ \\ MAURO GOBBI ${ }^{3}$ \\ PIETRO BRANDMAYR ${ }^{1}$ \\ ${ }^{1}$ Dipartimento B.E.S.T., Università della Calabria \\ Ponte Bucci 4b, I-87036, Rende (CS), Italy. \\ ${ }^{2}$ Scuola Superiore Sant'Anna, Istituto Scienze \\ della Vita, Piazza Martiri della Libertà, 33, 56127 \\ Pisa, (Italy) \\ ${ }^{3}$ Sezione di Zoologia degli Invertebrati e Idrobiologia \\ MUSE - Museo delle Scienze \\ Corso del Lavoro e della Scienza 3, I-38123 \\ Trento (Italy) \\ Correspondence: \\ Dr. Roberto Pizzolotto \\ E-mail: piz@unical.it
}

Keywords: Alps, Carabidae, ecological succession, mountain ecosystems, species traits.
Received January 15, 2016.

Revised June 7, 2016.

Accepted July 25, 2016.

\begin{abstract}
Background and purpose. Species traits have been extensively used by botanists to describe, group and rank species according to their functions. Recently, the multi-trait approach has been extended also to the animal assemblages. There is now growing evidence that interspecific traits-variability can have significant effects on community dynamics and ecosystem functioning. The aim of our study was to describe how the carabid species traits change in relation to an altitudinal sequence of habitat types.
\end{abstract}

Materials and methods. In this paper we weighted the species traits (dispersal power, diet, reproductive rhythm, chorology) of the Carabid beetles assemblages in nineteen sites in the Dolomites along an altitudinal sequence of habitat types (1000-2250 $m$ a.s.l.). Carabids have been sampled by means of pitfall traps.

Results. Species richness, activity density and species traits were not, or weakly, correlated with elevation, while they showed to be linked to the habitat type. Species traits, as taxa, showed to be not uniformly distributed along the sequence, with brachypterous species concentrated in high-altitude or climax environments mainly, and regional endemic species prevailing in high-altitude environments. Macropterous species with zoospermophagous species were found to increase with anthropogenic environmental disturbance.

Conclusions. The species traits analysis enabled us to shift the research focus from the taxonomic level to a biological more comprehensive level, opening the way for drawing more general ecologic models. Moreover it was possible to make inferences about the most successful carabid strategies in order to advance hypotheses on the historical colonization processes in the Alps.

\section{INTRODUCTION}

The term „trait” has been the focus of a debate about its meaning and 1 usage in ecological studies. Traits indeed can be analyzed either in terms of Darwinian fitness (1), hence functional ecologists proposed the term of "functional trait” (2-6), or in terms of specified functional attributes, leading to the term of „species trait” (7). A synthesis was proposed by Statzner et al (8) under the „biological trait” definition as including ecophysiological, life history and morphological features. Such definition was followed by Violle et al. (9) suggesting its application at the individual level, which is one of the conceptual backgrounds in Verberk et al. (10), where a way for transforming descriptive field studies into predictive studies has been proposed on the basis of species traits 
analysis; and in Pey et al. (11), where the development of a trait database and a thesaurus to improve data management has been proposed.

Traditionally, only plant traits have been used to describe the functional responses of the flora to environmental factors or specific disturbance factors $(12,13)$. Animal traits have been less often used to study community response to environmental changes, focusing on a single taxon with species classified according to few traits (14).

Recent papers and reviews have highlighted that functional traits (sensu Violle et al. (9)) can better describe the effects of global changes on ecosystem services than taxonomic parameters alone (15-18). Moreover, the classification of organisms on the basis of functional traits and assessing changes in functional trait composition is a promising way for testing hypothesis on the effect of global changes on ecosystem function $(19,20)$.

Recently Verberk et al. (10) have outlined that two principal problems in trait-based approaches are low discriminatory power and low mechanistic understanding, as a consequence of the poor knowledge on the linkage among traits within species, and on the context dependence of the relevance of a trait.

Carabid beetles (Coleoptera: Carabidae) are one of the best-known taxa in entomology, both in terms of spatial distribution and autoecology (21). They can be used as good ecological, environmental disturbance and management indicators (21); furthermore they are also early warning indicators $(22,23)$. Recently, several ecologists adopted their life strategies to assess the effect of environmental variables on the species assemblages, and the general consensus is that they work better with respect to the species richness per se $(17,24,25)$. Moreover, the creation of a database about Palearctic carabid species traits, freely available online (http://carabids.org; see also Homburg et al. (26)) was made possible by data accumulation and growing interest in a trait-based approach.

Even if there are several studies focusing on carabids diversity along elevation gradients (e.g. $(27,28))$, to our knowledge there are no researches aimed to describe how the carabid species traits change in relation to an altitudinal sequence of habitat types. It could be related to the absence of published data on the species traits belonging to the carabid mountain fauna.

As a step ahead for fulfilling such a lack of information we developed a research on the Dolomites (Eastern Italian Alps, (29)) aiming at increasing the knowledge of species traits in alpine carabids and at describing the carabid interspecific traits-variability in the context of alpine environmental diversity. Specifically, we tried to answer to the following questions: a) are there traits-habitat relationships along the altitudinal sequence of habitat types? And if so, b) are these relationships driven by the elevationtemperature connection?, and c) is it possible to use the species-traits approach to advance hypotheses on the colonisation processes?

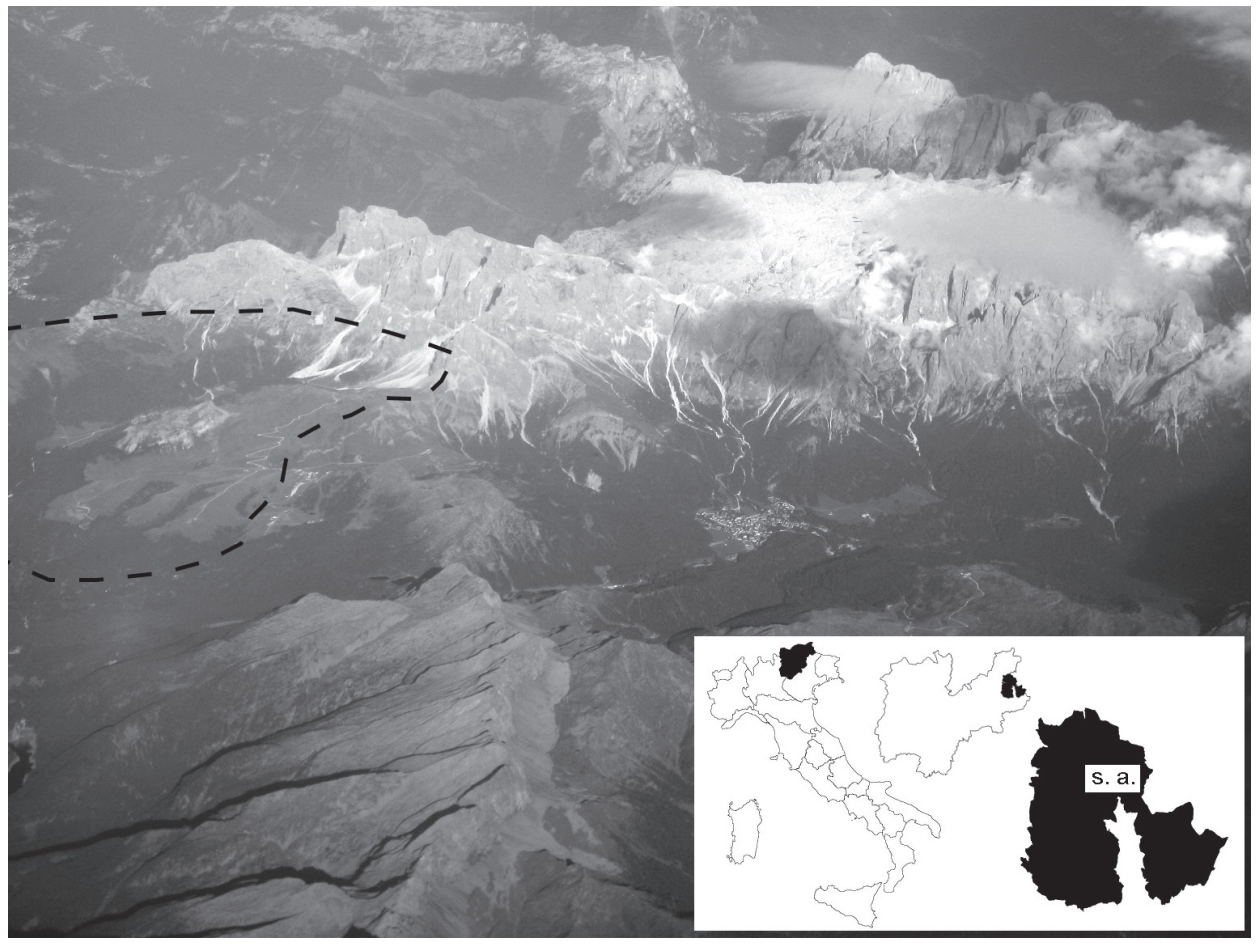

Figure 1. Study area location. The most part of the sampled sites are within the dashed line. In the Bottom righ rectagle, at left: Italy, the TrentinoAltoadige region in black; in the middle: the Trento province, Paneveggio park in black; at right: Paneveggio park, study area (s.a.) in white. 


\section{MATERIALS AND METHODS}

\section{Study area}

The study area is located within the „Paneveggio, Pale di S. Martino" Regional Park, in the SW Dolomites (Italian Alps; Fig. 1). The Dolomites are in the eastern part of the Italian Alps, and they belongs since 2009 to the UNESCO List of World Heritage (www.unesco.org). As part of the Alps, the Dolomites contribute to one of the most important European hotspot of biodiversity (see also Pizzolotto et al. (30)), and, at the same time, they are currently going through a series of profound changes whose biodiversity consequences are still largely unknown $(29,31)$ ).

The following three bioclimatic vegetational belts characterize the area $(32,33)$ : i) montane belt $(800-1750$ $\mathrm{m}$ a.s.l), originally characterized by silver fir wood sometimes mixed with beech, an increase in spruce forests being caused today by forest management practice; ii) subalpine belt (1750-2000 m a.s.l.), dominated by Vaccinio-Pieceetea associations, with brushwood rich in Ericaceae and bryophyta, on the upper limit of this belt there are also different types of secondary vegetation due to deforestation and mountain pasture, such as Nardetum alpigenum (Br.-Bl., 1949); iii) alpine belt (2000-2800 m a.s.l.), above treeline zone, the main associations are Seslerio-Caricetum sempervirentis (Br.-Bl. et Jenny, 1926) on calcareous bedrock and Festucetum halleri (Br.-Bl., 1926) on siliceous bedrock. The snow zone (2800-3342 m a.s.l.) has not been included in our study.

A total of 19 sites have been studied between 1000 $2250 \mathrm{~m}$ a.s.l. Sampling site environmental characteristics (ordered by vegetation type) are as follows (see Tab. 1 for topographic features; more phytosociologic details are reported in Pignatti-Wikus and Pignatti (34)).

\section{Pioneer vegetation}

F2, VV1. Plant-cushion formation on talus slope, over calcareus clastic drift.
F1. Carex firma pioneer grassland, with Dryas octopetala cushion, on rendzina soil, over calcareus clastic drift.

VV2. Rhododendron, Dryas, Vaccinium and sparse willows. Fragmentary vegetal formation just above the timberline, shading off to pioneer vegetation.

\section{Grasslands}

Se1, Se2, Se3. Sesleria varia and Carex sempervirens high altitude grassland on deep soil, over calcareous bedrock.

NA1, NA2. Nardus stricta pastures on acidic deep soil, over calcareous bedrock. Nardetum is the most frequent substitution vegetation when the wood is destroyed and replaced by herbaceous plants. (NA2 probably from a clear-cut of larch-fir vegetation around sixty years ago, natural re-forestation preveted by present grazing).

FH1, FH2, FH3. Festuca halleri grassland on deep soil with clay matrix, over an ignimbrite bedrock.

\section{Coniferous forests}

VV3. Mixed natural coniferous forest (spruce and larch).

VV4. Coniferous forest. This forest has an artificial origin, it's very dense and nearly lacking of brushwood.

PS1. Homogyno-Piceetum sphagnetosum, boreal spruce forest with dense Vaccinium brushwood and soil rich in Sphagnum.

PS2. Homogyno-Piceetum myrtilletosum, boreal spruce forest with soil poor in Sphagnum, characterised by Vaccinium mirtillus and $V$. vitis-idaea.

PM. Oxali-Piceetum montanum polypodietosum, montane spruce wood.

EP. Erico-Pinetum sylvestris, scots pine wood with Erica brushwood.

AP. Luzulo-Abietetum luzuletosum nivae, silver fir and spruce forest, where silver fir is favored by the type of soil and the sylviculture.

Table 1. First line: vegetation types (VV2 is a transition site). Second line: sample site's identification code. Following lines: main topographical features of the sampled sites (lines 1-3); percentage of vegetation cover (line 4); number of traps used in each sample site (line 5); species richness and abundance (lines 6 and 7, where aAD is the mean number of active individuals per trap in the standard period of 10 trapping days actually); year of sampling (line 8)

\begin{tabular}{|c|c|c|c|c|c|c|c|c|c|c|c|c|c|c|c|c|c|c|c|}
\hline & \multicolumn{3}{|c|}{ pioneer vegetation } & \multicolumn{3}{|c|}{ Seslerio-Caricetum } & \multicolumn{2}{|c|}{ Nardetum } & \multicolumn{3}{|c|}{ Festucetum } & \multirow[b]{2}{*}{ VV2 } & \multicolumn{4}{|c|}{ subalpine forests } & \multicolumn{3}{|c|}{ montane forests } \\
\hline & $\mathrm{F} 1$ & F2 & VV1 & Sel & $\mathrm{Se} 2$ & $\mathrm{Se} 3$ & NA1 & NA2 & FH1 & $\mathrm{FH} 2$ & $\mathrm{FH} 3$ & & VV3 & VV4 & PS1 & PS2 & PM & EP & AP \\
\hline altitude $\mathrm{m}$ a.s.l. & 2200 & 2250 & 2000 & 2200 & 2200 & 2200 & 2170 & 1910 & 2230 & 2245 & 2175 & 1950 & 1800 & 1850 & 1650 & 1780 & 1100 & 1040 & 1000 \\
\hline aspect & $\mathrm{N}$ & $\mathrm{N}$ & W & $\mathrm{N}$ & $\mathrm{N}$ & $\mathrm{N}$ & SSW & S & WSW & WSW & WSW & W & NW & SE & NW & NNE & NNE & ESE & WNW \\
\hline slope $^{\circ}$ & 30 & 35 & 35 & 5 & 20 & 15 & $5-20$ & 15 & $8-12$ & 25 & $5-7$ & 10 & 30 & 40 & 20 & 25 & $5-15$ & $25-30$ & 40 \\
\hline vegetation \% & 60 & 20 & 10 & 90 & 90 & 100 & 100 & 100 & 95 & 70 & 100 & 50 & 100 & 95 & 80 & 65 & 85 & 80 & 65 \\
\hline traps & 6 & 6 & 5 & 6 & 6 & 6 & 6 & 6 & 6 & 6 & 6 & 5 & 5 & 5 & 6 & 6 & 5 & 5 & 5 \\
\hline n.spp & 12 & 5 & 5 & 13 & 11 & 10 & 12 & 8 & 13 & 15 & 15 & 7 & 9 & 4 & 6 & 9 & 14 & 4 & 8 \\
\hline $\mathrm{aAD}$ & 5.7 & 6.97 & 2.0 & 7.5 & 7.49 & 6.1 & 5.3 & 2.9 & 5.8 & 6.9 & 8.5 & 2.2 & 10.6 & 1.1 & 11.5 & 26.5 & 16.4 & 5.1 & 2.8 \\
\hline year & 2008 & 2008 & 2009 & 2011 & 2011 & 2011 & 2009 & 2009 & 2012 & 2012 & 2012 & 2009 & 2009 & 2009 & 2008 & 2008 & 2012 & 2012 & 2012 \\
\hline
\end{tabular}




\section{Data collection}

Carabids were sampled by pitfall traps, i.e. plastic vessels, 6-10 m distanced, measuring $9 \mathrm{~cm}$ mouth diameter, and $11 \mathrm{~cm}$ depth, containing $200 \mathrm{cc}$ of an attractingpreserving mixture of wine vinegar $\mathrm{NaCl}$ saturated (35). The traps were emptied every 15-20 days from June to October (see Tab.1), during the activity season of high mountain carabid fauna. Five to six traps were used in each sites, as recommended by Kotze et al. (21), for a total of 107 traps.

Catches results were standardized in relation to the number of active traps and the number of days they were active, so that sampling over different years and/or different sites might be compared (21). The carabids abundance was computed as annual Activity Density (aAD), i.e. mean number of individuals per trap in the standard period of 10 trapping days (35).

\section{Species traits}

The following species traits were evaluated for each species.

\section{Wing morphology}

Wing morphology is a morphometric trait measured through metathoracic wing length: species were classified in macropterous plus pteridimorphic ( $\mathrm{m}$, high dispersal power) or brachypterous (b, low dispersal power). It has been found that dispersal power can be correlated to the age of a community, to the structural degradation of the environment and to the stability of a stage in a natural succession (35-38).

\section{Geographical range (chorotype)}

The distribution range of a given species mirrors the life strategies that led that species to live in a certain environment (39-41). Therefore, chorotype is the result of several morpho-functional traits that allow a species to survive in a particular environment for a sufficient time so that it is able to cope with the constrains imposed by evolution $(24 ; 42 ; 43)$.

We classified carabids distribution range on the basis of the peculiarity (43) to the studied region as follows, in descending order (I most peculiar, V least peculiar):

I - Regional endemic species

II - Central-montane European species

III - European species

IV - Euro-Asiatic, Euro-Siberian species

$\mathrm{V}$ - Palaearctic, Holoarctic, Circumpolar species

\section{Diet}

Carabids show a broad trophic spectrum, i.e. in alpine environments they can have a zoophagous specialized diet (zs; e.g. helicophagy, collembola), a zoophagous diet (z), an opportunistic diet feeding also on seeds (zf).
Notably, the species that have an opportunistic diet have an advantage when their habitat is altered and the number of species has been observed to increase in various kinds of ecosystem degradation $(35 ; 38)$.

\section{Reproductive rhythm}

Species can be spring breeders with summer larvae (s), autumn breeders (a) with or without adult estivation, twoyear breeders $(2 y)$. Species with shorter larval cycle are advantaged in ephemeral habitats and tend to increase along a degradation succession (35).

\section{Data Analysis}

Bootstrapping was applied („rich” function in Rossi (44)) to the data sets for comparing the actual number of sampled species with the expected (bootstrapped) number for evaluating the eventual amount of data lacking.

For each site, the percentage of species with that particular trait (e.g. the number of brachypterous species on the number of sampled species) and the corresponding aAD percentage (e.g. the aAD given by the brachypterous species on the total aAD) have been evaluated. It is useful to consider both the number of species and specimens because they have the potential to provide information about each trait from the historical and the present time point of view, respectively $(24 ; 45)$.

By means of R (46), we evaluated the Pearson's correlation between elevation and species traits. Average linkage fusion algorithm was applied for classification of sample sites based on chord distance, and species traits based on correlation coefficient $(47 ; 48)$. On the basis of aAD values, the following categories have been used to outline traits-habitat relationship $(24 ; 45 ; 49)$ :

- Central traits: traits with the maximum row-aAD among the sample sites (bold type in Tab. 2).

- Nuclear traits: traits with aAD higher than the mean row-aAD (underlined in Tab. 2).

- Orbital traits: traits with aAD lower than the mean row-aAD.

Principal Components Analysis (PCA) (47; 48; 50) was used for exploring variation in the distribution of the species traits among the sites, and to show what species traits affect the heterogeneity of the data by computing the correlation between species traits and the first two Principal Components, and the squared cosine between sample sites and the first two Principal Components, so that the most correlated traits can be linked to the highest cosine square sites laying on the same side of each Principal Component.

\section{RESULTS}

A total of 47 species has been sampled (see Appendix Table and Tab.1). The expected species number after bootstrapping is 53 (c.i. 47-59), while the species sampled are 
Table 2. Species traits relative weight in the sampled sites. Each trait has been weighted on the basis of the species abundance (ending with_aAD) and on the basis of the number of species (ending with_spp) showing that trait. Rows and columns have been splitted on the basis of species traits and sites classification (Fig. 2, groups A, B and C; and Fig. 3, groups 1 and 2, respectively).

\begin{tabular}{|c|c|c|c|c|c|c|c|c|c|c|c|c|c|c|c|c|c|c|c|c|}
\hline & & \multicolumn{4}{|c|}{ A } & \multicolumn{8}{|c|}{ B } & \multicolumn{7}{|c|}{$\mathrm{C}$} \\
\hline & & $\mathrm{F} 2$ & $\mathrm{~F} 1$ & VV1 & $\mathrm{VV}^{2}$ & Se3 & VV3 & VV4 & PS1 & PS2 & PM & $\mathrm{EP}$ & $\mathrm{AP}$ & $\mathrm{FH} 2$ & FH1 & $\mathrm{FH} 3$ & NA1 & Sel & $\mathrm{Se} 2$ & NA2 \\
\hline & I_aAD & $\underline{0.62}$ & $\underline{0.83}$ & 1.00 & $\underline{0.98}$ & 0.18 & 0.01 & & & 0.001 & 0.02 & 0.11 & 0.01 & 0.18 & 0.24 & 0.13 & 0.00 & 0.04 & 0.13 & \\
\hline & I_spp & 0.80 & $\underline{0.50}$ & 1.00 & $\underline{0.71}$ & $\underline{0.30}$ & 0.11 & & & 0.11 & 0.07 & 0.25 & 0.13 & 0.07 & 0.08 & 0.07 & 0.08 & 0.23 & 0.18 & \\
\hline & zs_aAD & 0.05 & $\underline{0.17}$ & $\underline{0.41}$ & 0.82 & 0.05 & 0.09 & 0.13 & 0.07 & 0.03 & 0.04 & 0.11 & 0.02 & 0.10 & 0.02 & 0.03 & & $\underline{0.25}$ & 0.01 & \\
\hline & b_spp & 1.00 & $\underline{0.67}$ & $\underline{0.80}$ & $\underline{0.71}$ & $\underline{0.70}$ & $\underline{0.67}$ & $\underline{0.75}$ & $\underline{0.67}$ & $\underline{0.78}$ & $\underline{0.71}$ & 1.00 & $\underline{0.88}$ & 0.20 & 0.23 & 0.27 & 0.33 & 0.38 & 0.55 & 0.25 \\
\hline & b_aAD & 1.00 & $\underline{0.96}$ & $\underline{0.91}$ & $\underline{0.98}$ & $\underline{0.95}$ & $\underline{0.97}$ & $\underline{0.91}$ & $\underline{0.95}$ & $\underline{0.98}$ & $\underline{0.90}$ & 1.00 & $\underline{0.99}$ & 0.25 & 0.35 & 0.24 & 0.23 & 0.08 & 0.54 & 0.08 \\
\hline & zs_spp & 0.20 & 0.25 & 0.20 & $\underline{0.29}$ & 0.20 & $\underline{0.44}$ & 0.50 & 0.50 & $\underline{0.44}$ & $\underline{0.36}$ & 0.50 & 0.25 & 0.13 & 0.08 & 0.07 & & 0.15 & 0.18 & \\
\hline & $2 y_{-}$spp & $\underline{0.20}$ & 0.17 & 0.40 & $\underline{0.29}$ & 0.20 & 0.22 & 0.25 & 0.33 & 0.22 & $\underline{0.21}$ & $\underline{0.25}$ & 0.13 & 0.07 & 0.08 & 0.07 & 0.17 & 0.08 & 0.18 & 0.13 \\
\hline 1 & z_aAD & $\underline{0.95}$ & 0.59 & 0.50 & 0.17 & 0.78 & 0.91 & $\underline{0.87}$ & $\underline{0.93}$ & $\underline{0.97}$ & $\underline{0.89}$ & $\underline{0.89}$ & 0.98 & 0.65 & 0.63 & 0.58 & 0.48 & 0.59 & $\underline{0.78}$ & 0.55 \\
\hline & II_spp & 0.20 & 0.08 & & 0.14 & 0.20 & $\underline{0.44}$ & $\underline{0.50}$ & 0.67 & $\underline{0.44}$ & $\underline{0.50}$ & 0.25 & $\underline{0.38}$ & 0.07 & 0.08 & 0.07 & 0.17 & 0.08 & 0.18 & 0.13 \\
\hline & III_spp & & 0.17 & & & & $\underline{0.22}$ & 0.25 & 0.17 & $\underline{0.22}$ & $\underline{0.21}$ & 0.25 & 0.13 & 0.13 & 0.08 & 0.13 & 0.17 & & 0.09 & \\
\hline & II_aAD & $\underline{0.38}$ & 0.13 & & 0.01 & $\underline{0.70}$ & $\underline{0.82}$ & 0.89 & $\underline{0.70}$ & $\underline{0.49}$ & $\underline{0.48}$ & 0.01 & 0.14 & 0.06 & 0.06 & 0.06 & 0.06 & 0.03 & $\underline{0.34}$ & 0.03 \\
\hline & $2 y \_a A D$ & $\underline{0.38}$ & 0.19 & $\underline{0.45}$ & 0.12 & $\underline{0.70}$ & $\underline{0.75}$ & 0.85 & $\underline{0.68}$ & $\underline{0.49}$ & $\underline{0.42}$ & 0.01 & 0.04 & 0.06 & 0.06 & 0.06 & 0.06 & 0.03 & $\underline{0.34}$ & 0.03 \\
\hline & III_aAD & & 0.01 & & & & 0.01 & 0.09 & 0.05 & 0.02 & $\underline{0.37}$ & 0.88 & $\underline{0.49}$ & 0.04 & 0.01 & 0.02 & 0.11 & & 0.01 & \\
\hline & a_spp & $\underline{0.60}$ & 0.67 & 0.40 & 0.29 & 0.40 & 0.33 & $\underline{0.50}$ & $\underline{0.50}$ & 0.44 & $\underline{0.57}$ & $\underline{0.50}$ & $\underline{0.50}$ & 0.40 & 0.46 & 0.40 & $\underline{0.50}$ & 0.46 & $\underline{0.55}$ & 0.25 \\
\hline & a_aAD & $\underline{0.58}$ & $\underline{0.64}$ & 0.14 & 0.05 & 0.22 & 0.23 & 0.07 & 0.28 & $\underline{0.49}$ & $\underline{0.54}$ & $\underline{0.89}$ & 0.93 & $\underline{0.69}$ & $\underline{0.84}$ & $\underline{0.51}$ & $\underline{0.62}$ & $\underline{0.61}$ & $\underline{0.63}$ & 0.10 \\
\hline & V_aAD & & & & 0.01 & 0.05 & $\underline{0.16}$ & 0.02 & $\underline{0.25}$ & 0.48 & 0.01 & & & 0.12 & 0.03 & $\underline{0.20}$ & $\underline{0.19}$ & $\underline{0.27}$ & 0.01 & $\underline{0.35}$ \\
\hline & V_spp & & & & 0.14 & $\underline{0.30}$ & $\underline{0.22}$ & $\underline{0.25}$ & 0.17 & 0.11 & 0.07 & & & 0.33 & $\underline{0.23}$ & $\underline{0.27}$ & 0.08 & $\underline{0.23}$ & 0.18 & $\underline{0.25}$ \\
\hline & z_spp & 0.80 & 0.50 & 0.60 & 0.57 & 0.50 & 0.56 & 0.50 & 0.50 & 0.56 & 0.57 & 0.50 & 0.75 & $\underline{0.67}$ & $\underline{0.69}$ & $\underline{0.67}$ & $\underline{0.67}$ & 0.54 & 0.55 & $\underline{0.75}$ \\
\hline & s_spp & 0.20 & 0.17 & 0.20 & 0.29 & $\underline{0.40}$ & $\underline{0.33}$ & 0.25 & 0.17 & $\underline{0.33}$ & 0.14 & & 0.25 & $\underline{0.47}$ & $\underline{0.46}$ & $\underline{0.40}$ & 0.25 & $\underline{0.46}$ & 0.27 & 0.63 \\
\hline & s_aAD & 0.05 & 0.17 & $\underline{0.41}$ & 0.02 & 0.08 & 0.02 & 0.09 & 0.05 & 0.02 & 0.02 & & 0.03 & $\underline{0.25}$ & 0.10 & $\underline{0.41}$ & $\underline{0.31}$ & $\underline{0.36}$ & 0.03 & 0.87 \\
\hline 2 & zf_spp & & 0.17 & 0.20 & 0.14 & 0.30 & & & & & 0.07 & & & 0.20 & $\underline{0.23}$ & $\underline{0.27}$ & $\underline{0.25}$ & 0.31 & $\underline{0.27}$ & $\underline{0.25}$ \\
\hline & IV_aAD & & 0.04 & & & 0.07 & & & & 0.001 & 0.12 & 0.01 & 0.36 & $\underline{0.61}$ & 0.66 & $\underline{0.59}$ & $\underline{0.63}$ & 0.66 & $\underline{0.52}$ & $\underline{0.62}$ \\
\hline & IV_spp & & 0.25 & & & 0.20 & & & & 0.11 & 0.14 & 0.25 & $\underline{0.38}$ & $\underline{0.40}$ & $\underline{0.54}$ & $\underline{0.47}$ & $\underline{0.50}$ & $\underline{0.46}$ & 0.36 & 0.63 \\
\hline & zf_aAD & & 0.20 & 0.09 & 0.01 & 0.17 & & & & & 0.07 & & & $\underline{0.25}$ & $\underline{0.35}$ & $\underline{0.39}$ & 0.52 & 0.16 & 0.21 & $\underline{0.45}$ \\
\hline & m_aAD & & 0.04 & 0.09 & 0.02 & 0.05 & 0.03 & 0.09 & 0.05 & 0.02 & 0.10 & & 0.01 & 0.75 & $\underline{0.65}$ & $\underline{0.76}$ & $\underline{0.77}$ & 0.92 & $\underline{0.46}$ & 0.92 \\
\hline & m_spp & & 0.33 & 0.20 & 0.29 & 0.30 & 0.33 & 0.25 & 0.33 & 0.22 & 0.29 & & 0.13 & 0.80 & $\underline{0.77}$ & $\underline{0.73}$ & $\underline{0.67}$ & $\underline{0.62}$ & $\underline{0.45}$ & $\underline{0.75}$ \\
\hline
\end{tabular}

$89 \%$ of the expected ones.The actual species richness is within confidence intervals, hence, sampling intensities was adequate. Species a AD shows a wide range of values from the very low aAD of Clivina fossor (0.022 in NA1) to the maximum of 12,754 for Calathus micropterus in PS2. The total aAD per site (see Tab.1) ranges from 1.045 in VV4 to 26.459 in PS2. There is no correlation between $\mathrm{aAD}$ and altitude $(\mathrm{r}=0.16, \mathrm{p}=0.5)$.

Festucetum is the habitat type were the highest number of species (see Tab.1) has been collected (15 species in FH2 and $\mathrm{FH} 3,13$ species in $\mathrm{FH} 1$ ). However, also the montane spruce wood PM and the Seslerio-Caricetum Sel show high $\alpha$-diversity (14 and 13 species respectively). A low number of species has been recorded in talus slopes ( 5 species both in VV1 and in F2), forest VV4 (4 species) and scots pine wood EP ( 4 species). There is no correlation between number of species and altitude $(r=0.35, p=0.15)$.

Brachypterous species are dominant in the study area, except in Festucetum and Nardetum where macropterous and dimorphic carabids are generally better represented (see Tab. 2). Low correlation between brachypterous/macropterous species and altitude has been found (see Tab. 3).

Considering the feeding behaviour (Tab. 2), zoophagy is always the prevalent feeding strategy. Specialized zoophagous carabids have been collected in F1 and especially in forests sites (VV3, VV4, PS1, PS2, PM, EP), while they are totally absent from Nardetum. Zoospermophagous carabids are particularly abundant in Seslerio- 
Table 3. Correlations and p-value between species traits and altitude.

\begin{tabular}{|ccc|}
\hline species traits & correlation & $\mathrm{p}$ \\
\hline b spp & -0.53 & $<0.05$ \\
b aAD & -0.47 & $<0.05$ \\
m spp & 0.53 & $<0.05$ \\
m aAD & 0.47 & $<0.05$ \\
zs spp & -0.58 & $<0.01$ \\
z aAD & -0.48 & $<0.05$ \\
zf spp & 0.65 & $<0.01$ \\
zf aAD & 0.51 & $<0.05$ \\
II spp & -0.61 & $<0.01$ \\
III spp & -0.51 & $<0.05$ \\
III aAD & -0.83 & $<0.001$ \\
s spp & 0.52 & $<0.05$ \\
\hline
\end{tabular}

Caricetum, absent in F2 sites and in VV3, VV4, PS1, PS2, $\mathrm{EP}$ and AP forests. Low correlation has been found between specialized zoophagous and zoospermophagous species and altitude (Tab. 3)

Regarding to chorology, endemic species are found mainly in environments with pioneer vegetation (F1, F2, VV1 and VV2), while they are absent or sporadic in Festucetum, Nardetum, in boreal and montane forests. In Festucetum carabids have a typical euroasiatic/eurosibiric distribution, whereas in Seslerio-Caricetum the chorological spectrum is wider. In forests the prevalent forms are of central montane or European distribution. Only the species with European distribution are highly and negatively correlated with altitude $(r=-0.83, p<0.001)$, while low correlation has been found for central montane species (Tab. 3)

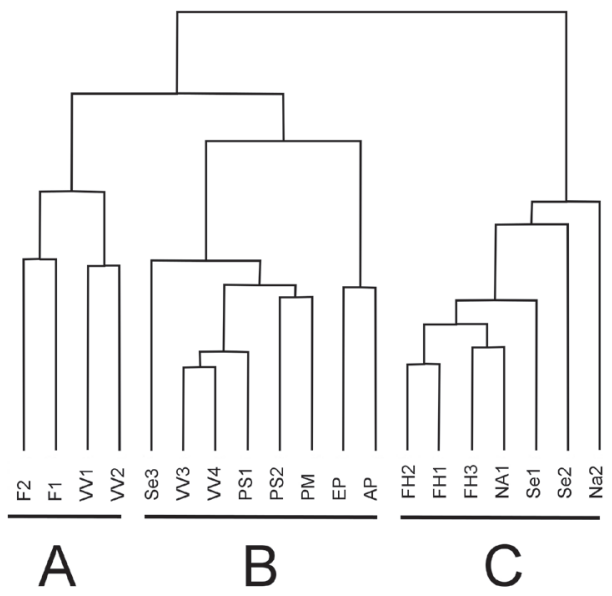

Figure 2. Classification of sample sites on the basis of chord distance and average linkage fusion algorithm. It is possible to identify three main clusters: pioneer vegetation in cluster $A$, forests in cluster $B$, and alpine grassland in cluster $C$. Site Se3 does not fall in this group, while it stands alone in cluster $B$.
The reproductive rhythms of the alpine grassland species are equally characterized by spring and autumn breeders, while in forest sites and, in certain cases, in talus slopes, autumn breeders tend to prevail (see Tab. 2). Low correlation between spring breeders and altitude has been found (Tab. 3).

The dendrogram in Figure 2 shows the classification of the sites on the basis of the weight of species traits (see Methods), where it is possible to identify three main clusters. The four sites that match with pioneer vegetation (F2, F1, VV1 and VV2) group together in cluster A. The forest sites, both boreal and montane, establish group $\mathrm{B}$. Alpine grassland (FH2, FH1, FH3, NA1, Se1, Se2 and NA2) characterizes cluster $\mathrm{C}$, but $\mathrm{Se} 3$ does not fall in this group, while it stands alone in cluster $\mathrm{B}$, isolated from the other sites of the same group.

The classification of the species traits (Fig. 3) has been used with that of sites (Fig.2) for reordering Table 2, so that it should be more clear in what habitat (i.e., group of sites) the group of species traits are the optimal life strategies. The traits-habitat relationship has been further emphasized primarily through the identification of the central traits and secondarily of the nuclear ones.

Species traits have been classified into two opposite groups. The first (Fig.3 group 2, and Fig.2 group C) designates alpine grasslands, with macroptery, broad distribution range (i.e. IV and $\mathrm{V}$ categories), opportunistic diet (i.e. zoo-phytophagy), early reproduction (i.e. spring breeders); the second (Fig.3 group 1, and Fig.2 groups A and $\mathrm{B}$ ) identifies the environment with pioneer vegetation and forests, with the rest of the species traits (see Tab. 2).

Regional endemism is clearly characterizing the environment with pioneer vegetation, where most of the carabids belong to the I chorological category, while the opposite is true for the rest of the sampled habitats. This environment is marked by brachypterism and zoophagy or specialized zoophagy, which are species traits very frequent in forests also. The same holds true for the reproduction rhythm, where Autumn breeders and two-year breeders are the most abundant, while the range of distribution not strictly peculiar to the Alpic region (i.e., categories II and III) is more frequent in forests only.

In the alpine grasslands the species with large distribution range (IV category) are abundant, while those widespread over very large area (i.e., category V) do not show clear concentration. Macropterism clearly characterizes this environment, with opportunistic feeding strategy. Central values have been found for spring breeders.

The classification of Figure 3 has a predictive value, being the dendrogram of the species traits evaluated on the basis of the coefficient of correlation; those elements which better follow the linear model are found within the same group. 


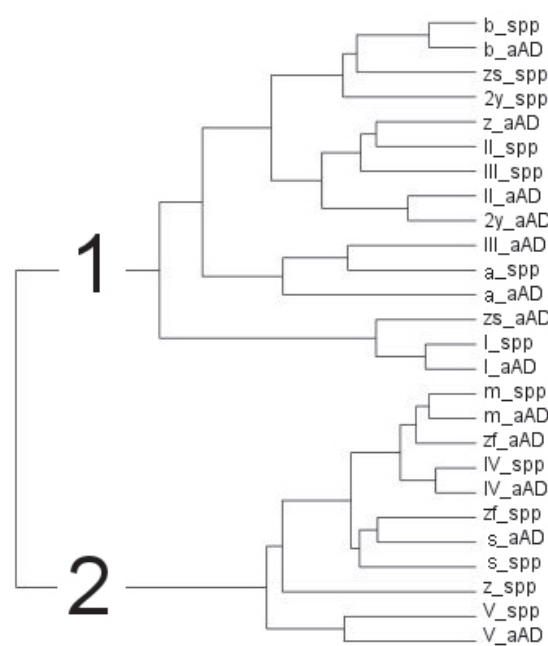

Figure 3. Classification of species traits on the basis of correlation coefficient and average linkage fusion algorithm. Two opposite groups are clearly identifiable, where those elements which are positively correlated are found within the same group.

Hence membership to group 1 (Fig. 3) means negative correlation to the traits belonging to group 2, while inside each group the farther the traits the less correlation among them (see Fig. 1s in online version). The dispersal power has
Table 4. Correlation and p-value (<0.05 only) among the species traits and the first two axes (i.e. Principal Components).

\begin{tabular}{|lrrccc|}
\hline Axis 1 & $\begin{array}{c}\text { correla- } \\
\text { tion }\end{array}$ & p-value & Axis 2 & $\begin{array}{c}\text { correla- } \\
\text { tion }\end{array}$ & p-value \\
\hline m_aAD & 0.95 & 0.0000 & z_aAD & 0.69 & 0.0012 \\
IV_aAD & 0.93 & 0.0000 & III_spp & 0.66 & 0.0022 \\
m_spp & 0.91 & 0.0000 & II_spp & 0.62 & 0.0049 \\
zf_aAD & 0.89 & 0.0000 & II_aAD & 0.50 & 0.0303 \\
IV_spp & 0.88 & 0.0000 & z_s_aAD & -0.79 & 0.0001 \\
zf_spp & 0.81 & 0.0000 & I_spp & -0.91 & 0.0000 \\
s_spp & 0.78 & 0.0001 & I_aAD & -0.94 & 0.0000 \\
s_aAD & 0.73 & 0.0004 & & & \\
V_spp & 0.52 & 0.0229 & & & \\
z_aAD & -0.55 & 0.0157 & & & \\
II_aAD & -0.58 & 0.0092 & & & \\
2y_aAD & -0.64 & 0.0035 & & & \\
II_spp & -0.66 & 0.0021 & & & \\
2y_spp & -0.73 & 0.0003 & & & \\
z_s_spp & -0.88 & 0.0000 & & & \\
b_spp & -0.91 & 0.0000 & & & \\
b_aAD & -0.95 & 0.0000 & & & \\
\hline & & & & & \\
\hline
\end{tabular}

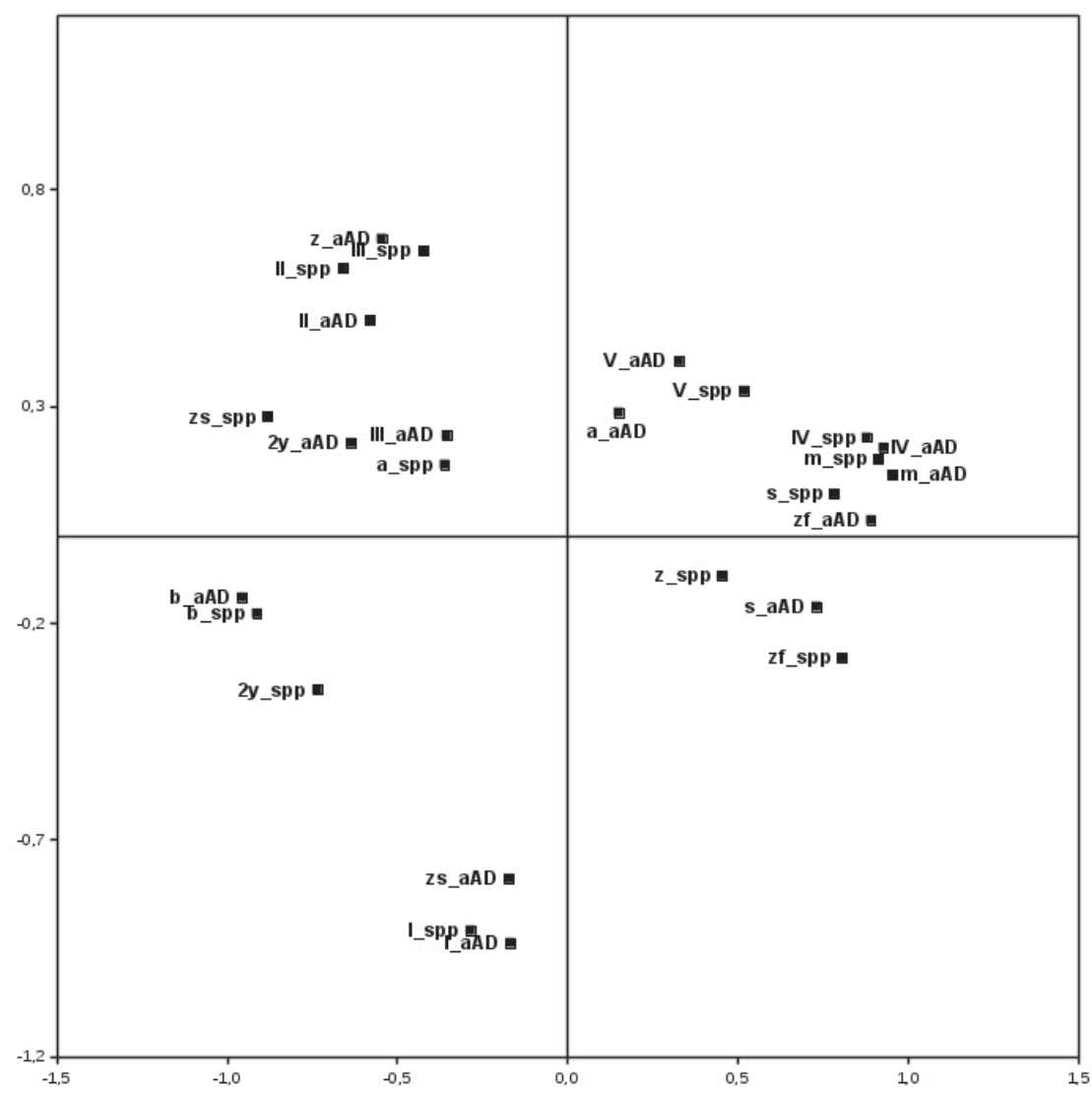

Figure 4. Species traits ordination by means of PCA. It shows the importance of the co-occurence of two or more species traits, it is based on the correlation among species traits, and it was possible to explain the $51 \%$ and the $22 \%$ of the total variance with the first and second axis respectively. 
been splitted into two groups. Brachypterism is in group 1, with brachypterous species richness showing high correlation with the brachypterous species abundance ( $r=0.91$, $\mathrm{p}<0.001)$. Moreover, when the brachypterism is dominant it is likely that many species show specialized zoophagous $\operatorname{diet}(\mathrm{r}=0.69, \mathrm{p}<0.01)$, and two year biological cycle $(\mathrm{r}=0.66$, $\mathrm{p}<0.01)$. Endemism is the trait less correlated with brachypterism $(\mathrm{r}=0.47, \mathrm{p}<0.05)$, moreover when endemic species are dominant it is likely that many individuals show specialized zoophagous diet $(r=0.72, p<0.001)$. Macropterism is the most negatively correlated trait with brachypterism (i.e., the more the low dispersal species the higher the high dispersal species, and viceversa); as a member of group 2, these species traits are the opposite type of those of group 1. The opposing traits are feeding strategy with opportunistic diet (group 2) vs. specialized zoophagy (group 1), spring vs. autumn breeders, very large distribution area vs. European or narrower distribution area.

Data ordination by means of PCA shows the importance of each species trait or the co-occurence of two or more species traits for the heterogeneity of the data.

Figure 4 shows the ordination of species traits: brachypterism and specialized zoophagy are located on the left part of the first axis (but the latter is correlated to the second axis also), while macroptery is located on the right part as well as zoo-phytophagy and IV chorological cat- egory (see Tab.4 for the correlations and p-values among species traits and first and second axes). First axis is therefore largely responsible for the dispersal power, i.e. low vs. high dispersal is the main factor affecting data diversity. Other factors (diet and distribution area) are likely to interact with the high dispersal power.

The second axis (Fig.4 and Tab.4) is characterized by the juxtaposition of two chorological categories, i.e. regional endemism vs. mountain distribution, while zoophagy and European distribution marks the upper part, and specialized zoophagy identifies the bottom part of the axis. The biogeographical history is then the main factor responsible for data diversity when dispersal power (i.e., first PCA axis) is not taken into account, while it is likely that prey diversity plays a secondary role.

Figure 5 shows the ordination of sample sites: on the left part of the first axis (i.e. the low dispersal part) there are the forest and high altitude sites, on the right part (i.e. the high dispersal part) there are the sites where grazing is present (see Tab. 5 for the importance of the linkage between sample sites and first and second axes). Only the sites in the left part of the first axis have been ordered along the second axis too, with forest sites in the upper part and talus slope sites or sites at the altitudinal vegetation limit in the lower part of the axis.

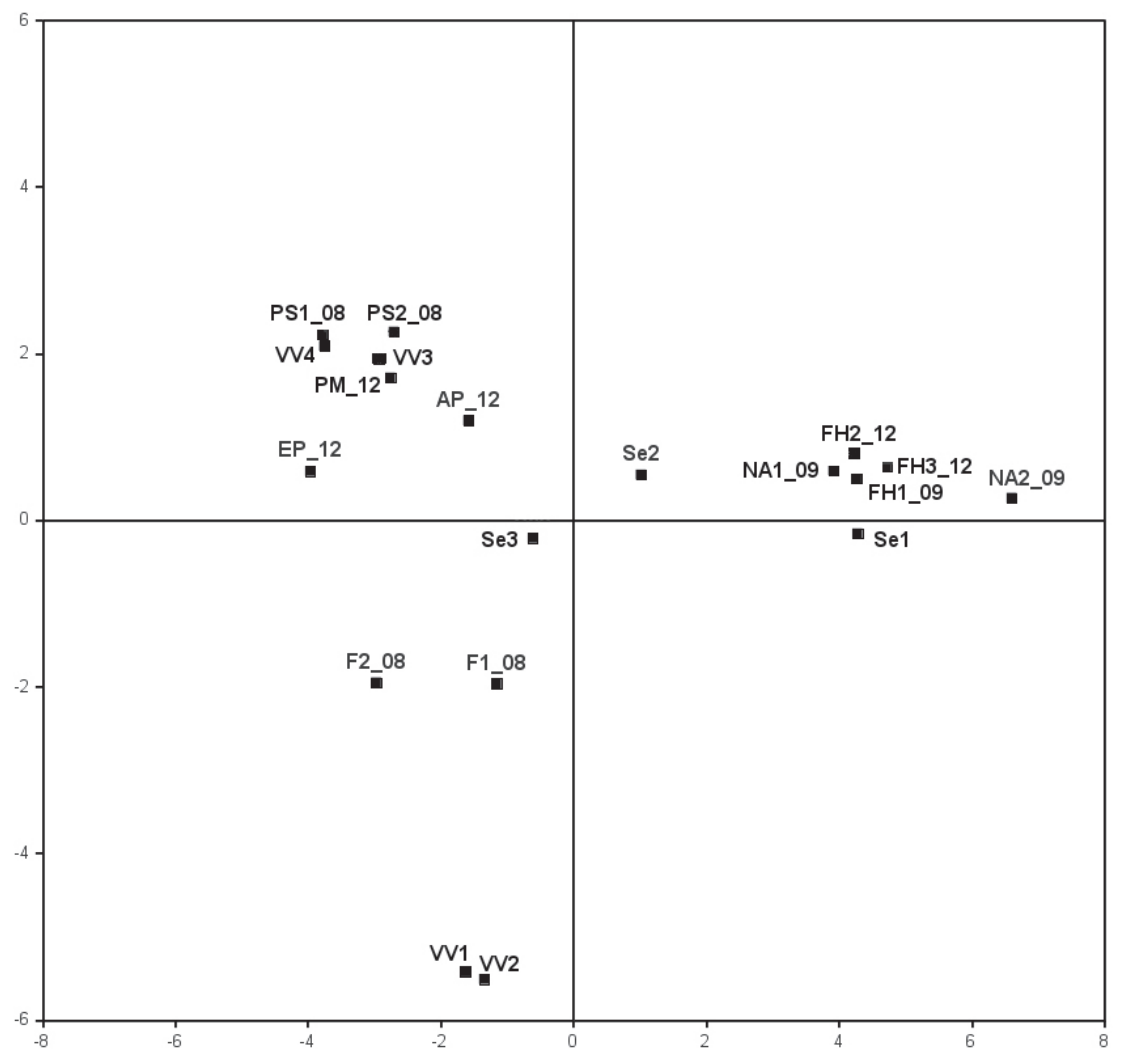

Figure 5. Sample sites ordination by means of PCA, where the $51 \%$ and the $22 \%$ of the total variance is linked to the first and second axis respectively. 
Table 5. Squared cosine values (cos2) giving the importance of the linkage between sample sites and axes (i.e. Principal Components).

\begin{tabular}{|lccc|}
\hline Axis 1 & cos2 & Axis 2 & $\cos 2$ \\
\hline FH3 & 0.944 & VV1 & 0.810 \\
FH2 & 0.812 & VV2 & 0.706 \\
FH1 & 0.778 & PS2 & 0.240 \\
NA2 & 0.771 & F1 & 0.228 \\
Se1 & 0.742 & PM & 0.217 \\
NA1 & 0.652 & PS1 & 0.187 \\
PM & 0.569 & VV3 & 0.176 \\
PS1 & 0.540 & VV4 & 0.158 \\
VV4 & 0.509 & F2 & 0.131 \\
VV3 & 0.403 & AP & 0.063 \\
EP & 0.391 & Se2 & 0.043 \\
PS2 & 0.345 & FH2 & 0.029 \\
F2 & 0.301 & FH3 & 0.017 \\
Se2 & 0.156 & NA1 & 0.015 \\
AP & 0.111 & FH1 & 0.010 \\
F1 & 0.078 & EP & 0.008 \\
VV1 & 0.072 & Se3 & 0.003 \\
VV2 & 0.041 & Se1 & 0.001 \\
Se3 & 0.025 & NA2 & 0.001 \\
\hline
\end{tabular}

\section{DIsCusSION}

Our work is one of the few attempts to simultaneously test the effect of habitat diversity gradient (along elevation) on carabid species richness, activity density, and species traits distribution. The concept of trends in mountain ecosystems is not new and explanations such as gradient of area, climatic gradient, isolation and exchanges among zonal communities are involved and interacting among each other (see Lomolino (30) and citations therein). Traditional studies are mainly examining the variation of species diversity along a gradient, while we focused on how this diversity can take shape through biological traits.

Our first question (a) has found a positive answer, because species richness, activity density and species traits change in relation to the habitat type, while they are found not to be affected by elevation gradient, i.e. a negative answer to our second question (b). This pattern shows clear differences in trait values across gradients with good discriminatory power (see also Verberk et al. (10)), while it differs with respect to the trends commonly described in other mountain chains where at least the species richness changes, by decreasing, with the elevation (51).

Carabid species assemblages are characterised mainly by both generalist and specialized species. They are moderately species rich, composed of 4-15 active carabids, and this is consistent with previous studies (52).
On the basis of the ordination analysis, as the bioclimatic belts follow an altitudinal gradient, we can reasonably suppose an indirect effect of elevation on the distribution of species traits, while there is no clear evidence that elevation per-se is directly affecting the distribution of species traits.

Figure 4 shows that the heterogeneity of the data is mainly determined by the different dispersal power of sampled species. It has already been found $(26 ; 37 ; 53-55)$ that the low dispersal power is related to environmental conditions of stability, while the high dispersal power represents a form of adaptation to environmental conditions of natural instability (i.e. ecological succession) or man induced disturbance. On accordance with existing literature, along the first ordination axis of the sampling sites (Fig.5) the sites characterized by anthropogenic environmental disturbance (i.e., grazing) are to the right, while to the left there are the forest sites where there is no grazing, logging is not heavy and is practiced with very long temporal rhythm. The first axis of the PCA indicates that the anthropogenic disturbance given by grazing is the main factor driving the distribution of the species traits within the study area. Most likely the opportunistic diet (i.e., zoo-phytophagy), along with macropterism, could be a positive life strategy in the alpine pastures. In sites non- (or very little) disturbed by man, or at climax stage, such as forests, the brachypterism is probably a form of better adaptation to environmental stability, along with zoo-specialised feeding strategy.

Excluding the anthropogenic disturbance factor (i.e., the right part of the first PCA axis), within the environments unaffected by human activities (i.e., the sites on the left part of the first axis) the species traits diversity mirrors the biogeographic history that has shaped those environments. It is therefore likely that the high-altitude environments reflect the strong influence of the glacial periods, when endemic species of „nunatakker“ and „massif de refuge" evolved, while forests represent the final stage (i.e., climax) of post-glacial ecological succession colonized by species with wider distribution area.

\section{Hypotheses on the colonisation processes.}

On the basis of the results about the first two questions ( $a, b$ in the Introduction) previously discussed, in the following we propose an interpretation of the link between species traits, habitat type and colonisation processes in the Alps (question c; cp. Verberk et al. (10).

\section{Pioneer vegetation and talus slope habitats}

Most alpine stenoendemic Coleoptera are confined in marginal districts of the Alps and tend to rarefy toward the central part of this mountain range, as a consequence of a non uniform postglacial diffusion from the most important biogeographical refugia $(56 ; 57)$. The fauna of the 
inner part of the Alps is primarily characterized by longdistance reimmigrants who colonized the most intensely iced zones after the Würmian period $(58 ; 59)$. In our study, pioneer vegetation and talus slope habitats are clearly marked by the presence of endemic species (e.g. Trechus dolomitanus, Nebria diaphana, Pterostichus schaschli), consistently with the hypothesis that the study area played the role of 'massif de refuge' in glacial era (60).

Losing the flight ability (i.e. brachypterism) is a positive adaptation for living in isolation surrounded by harsh conditions, as can be frequently seen in eualpin insects that survived Pleistocenic glaciacions $(56 ; 61)$. This is probably the evolutionary pathway followed by the carabids of the high altitude environments in our study area, where almost $70 \%$ of the collected species are brachypterous. Furthermore, low dispersal power is a successful strategy in such a clastic litic soil with high hydric stability and slow ecological succession dynamic $(35 ; 37)$.

Our data suggest a feeding strategy-habitat relationship, so that it may be that the reduction of preying spectrum due to the particular ecological conditions of the high altitude environments drives the feeding behaviour to the specialized zoophagy shown by Carabus creutzeri and Cychrus caraboides (helicophagous) or Notiophilus biguttatus (springtails).

It has been generally found that species with longer larval cycles tend to increase in less disturbed habitat (35). Our results confirm the data: indeed, carabids with two years cycle are better represented in talus slopes and forests (Tab. 2, Figs. 4 and 5).

\section{Grasslands}

The postglacial colonisation of the Alps by the species adapted to refugia or nunatakker (i.e., present endemic species) did not affect alpine grasslands, where there were scarce suitable ecological conditions for that species (56; 57).

Endemic species of our study area gradually decrease through the alpine grasslands to the forests. A slight difference is shown between Seslerio-Caricetum, where central montane species are still present, and Festucetum, where carabids with very wide distribution range are prevailing, probably as a consequence of different bedrock (calcareous vs. siliceous, (52). Nardetum is a different case, where as a consequence of intensive grazing, soil has become more acidic and compact, and endemic species, generally sedentary, couldn't find favorable conditions to set in (60). These pastures host broad chorology species, and the only endemism is Carabus bertolinii in the higher Nardetum (NA1) site.

In grasslands, the vast majority of species are macropterous (Tab. 2). Hydric instability is one of the key features of Festucetum siliceous soil, more similar to arctic tundra rather than to habitats on calcareous or dolomia bedrock (32). This instability is translated for carabids into a remarkable presence of high dispersal species, both macropterous and pteridimorphic. Differently, SeslerioCaricetum soil is more permeable and therefore less hydric instable, indeed dispersal power is lower.

The sampled Nardetum is characterized by grazing disturbance (followed by soil acidification), as a consequence carabids of these pastures have a strong dispersal power (nearly $80 \%$ on average).

Interestingly, specialized zoophagous species are scarce in grasslands and completely absent in Nardetum, where they are replaced by opportunistic carabids (Tab. 2). This data are consistent with the hypothesis that the specialized predator is the most sensitive element and disappears in the most disturbed habitat, where a flexible diet becomes more advantageous.

In alpine prairies the proportion between spring and autumn breeders seems to be quite balanced. Species with shorter larval cycle, that is spring breeders, tend to prefer ephemeral and/or instable habitats: they increase in Festucetum and Nardetum, while in Seslerio-Caricetum there is a prevalence of autumn breeders (Tab. 2). It is important to highlight that the distinction between autumn and spring breeders is not strongly marked in alpine environments, as they both are synchronous in their breeding seasons, being forced to lay their eggs after snow melting (62).

\section{Forests}

The chorological spectrum of forests is dominated by montane centraleuropean or European species; only the long-distance reimmigrant Carabus creutzeri, found in boreal forests, and Abax pilleri, caught in montane site, are endemic. We hypothesize that in these habitat the endemic carabids did not have the time to locally evolve; the absence of strong disturbing factors leads us to exclude that the scarcity of endemisms is due to an unstable ecosystems. Moreover, recent origination (Quaternary) of alpine spruce forests could have not facilitated the development of a petrophilous fauna (32).

The crowding of low dispersal carabids in alpine forests (Tab. 2) is probably due to the stability of the ecological succession reached in this environment (37).

Carabids found in talus slopes and forests show similar feeding strategy: specialized zoophagous diet seems to be a positive strategy, even if the overall preference is for a generalized zoophagous one (Tab. 2)

In forests, the success of the trophic specialization can be attributed to the heterogeneity of trophic ecological niches, supported by the microclimatic complexity, leading to the diversification of dietary strategies. Carabus auronitens, for example, is able to exploit both vertical and horizontal vegetation structure (63-65). 


\section{CONCLUSION}

Employing species traits as a surrogate of species taxonomy allows drawing more general ecologic models (66). Habitat classification using species traits yields different information levels: it is possible to make inferences about the most successful carabid strategies, the degree of ecological succession, habitat and water stability, disturbance factors along a gradient.

Despite the scarcity of knowledge about carabids of the Alps (52), a close inspection of species traits provides unique insights about species adaptations and life-cycle plasticity $(11 ; 67)$.

Reproductive rhythmicity surely deserves more attention, as changing temperatures may have significant impacts on the successful completion of life cycles $(68 ; 69)$.

Our study outlines a framework for more detailed future studies (as suggested by (10), where comparison across a time scale is essential to continue to evaluate critically trends and patterns in carabid alpine assemblages. Moreover, it might be useful to acquire data about other zoocenosis and to evaluate if similar patterns in community structure across similar habitat sequences are present (30).

Acknowledgments: This research was supported by the Paneveggio and Pale di S. Martino Regional Park; the Italian Ministry for University (MIUR, PRIN Project 200947YRB9); and co-financed by Muse-Science Museum of Trento.

\section{REFERENCES}

1. ARNOLD S J 1983 Morphology, performance and fitness. Am Zool 23: 347-361 http://dx.doi.org/10.1093/icb/23.2.347

2. CALOW $P 1987$ Towards a definition of functional ecology. Functional Ecology 1: 57-61 http://dx.doi.org/10.2307/2389358

3. KEDDY P 1992 A pragmatic approach to functional ecology. Functional Ecology 6: 621-626 http://dx.doi.org/10.2307/2389954

4. ACKERLY D D 2003 Community assembly, niche conservatism, and adaptive evolution in changing environments. International Journal of Plant Sciences 164 (S3): S165-S184 http://dx.doi.org/10.1086/368401

5. MCGILL B J, ENQUIST B J, WEIHER E, WESTOBY M 2006 Rebuilding community ecology from functional traits. Trends Ecol Evol 21 (4): 178-85

6. POORTER L, WRIGHT S J, PAZ H, ACKERLY D D, CONDIT R, IBARRA-MANRÍQUEZ G, HARMS K E, LICONA J C, MARTÍNEZ-RAMOS M, MAZER S J, MULLER-LANDAU H C, PENAA-CLAROS M, WEBB C O, WRIGHT I J 2008 Are functional traits good predictors of demographic rates? Evidence from five Neotropical forests. Ecology. 89 (7): 1908-1920.

7. POFF N L 1997 Landscape filters and species traits: towards mechanistic understanding and prediction in stream ecology. Journal of the north american Benthological society: 391-409 http://dx.doi.org/10.2307/1468026

8. STATZNER B, HILDREW A G, RESH V H 2001 Species traits and environmental constraints: entomological research and the history of ecological theory. Annual Review of Entomology 46: 291316 http://dx.doi.org/10.1146/annurev.ento.46.1.291
9. VIOLLE C, NAVAS M, VILE D, KAZAKOU E, FORTUNEL C, HUMMEL I, GARNIER E 2007 Let the concept of trait be functional!. Oikos 116: 882-892 http://dx.doi.org/10.1111/j.0030-1299.2007.15559.x

10. VERBERK W, VAN NOORDWIJK C, HILDREW A 2013 Delivering on a promise: integrating species traits to transform descriptive community ecology into a predictive science. Freshwater Science 32: 531-547 http://dx.doi.org/10.1899/12-092.1

11. PEY B, NAHMANI J, AUCLERC A, CAPOWIEZY, CLUZEAU D, CORTET J, DECAENS T, DEHARVENG L, DUBS F, JOIMEL S 2014 Current use of and future needs for soil invertebrate functional traits in community ecology. Basic and Applied Ecology 15: 194-206 http://dx.doi.org/10.1016/j.baae.2014.03.007

12. THUILLER W, LAVOREL S, MIDGLEY G, LAVERGNE $S$, REBELO T 2004 Relating plant traits and species distributions along bioclimatic gradients for 88 Leucadendron taxa. Ecology 85: 1688-1699 http://dx.doi.org/10.1890/03-0148

13. DE BELLO F, LEPS J, SEBASTIÀ M 2005 Predictive value of plant traits to grazing along a climatic gradient in the Mediterranean. Journal of Applied Ecology 42: 824-833 http://dx.doi.org/10.1111/j.1365-2664.2005.01079.x

14. GRIME JP, PIERCE S 2012 The evolutionary strategies that shape ecosystems. John Wiley and Sons, p 264 http://dx.doi.org/10.1002/9781118223246

15. HOOPER D U, CHAPIN III F, EWEL J, HECTOR A, INCHAUSTI P, LAVOREL S, LAWTON J, LODGE D, LOREAU M, NAEEM S 2005 Effects of biodiversity on ecosystem functioning: a consensus of current knowledge. Ecological monographs 75: 3-35

16. DIAZ S, LAVOREL S, DE BELLO F, QUÉTIER F, GRIGULIS K, ROBSON T M 2007 Incorporating plant functional diversity effects in ecosystem service assessments. Proceedings of the National Academy of Sciences 104: 20684-20689 http://dx.doi.org/10.1073/pnas.0704716104

17. GOBBI M, FONTANETO D 2008 Biodiversity of ground beetles (Coleoptera: Carabidae) in different habitats of the Italian Po lowland. Agriculture, ecosystems \& environment 127: 273-276 http://dx.doi.org/10.1016/j.agee.2008.04.011

18. DE BELLO F, LAVOREL $S$, DIAZ $S$, HARRINGTON R, CORNELISSEN J H, BARDGETT R D, BERG M P, CIPRIOTTI P, FELD C K, HERING D 2010 Towards an assessment of multiple ecosystem processes and services via functional traits. Biodiversity and Conservation 19: 2873-2893

19. DIAZ S, LAVOREL S, CHAPIN III F S, TECCO P A, GURVICH D E, GRIGULIS K 2007 Functional diversity - at the crossroads between ecosystem functioning and environmental filters. In: Canadell J G, Pataki D Pitelka L (eds) Terrestrial ecosystem in a changing world. Springer, Berlin, Heidelberg p 81-91

20. MORETTI M, LEGG C 2009 Combining plant and animal traits to assess community functional responses to disturbance. Ecography 32: 299-309 http://dx.doi.org/10.1111/j.1600-0587.2008.05524.x

21. KOTZE D J, BRANDMAYR P, CASALE A, DAUFFY-RICHARD E, DEKONINCK W, KOIVULA M J, LOEVEI G L, MOSSAKOWSKI D, NOORDIJK J, PAARMANN W, PIZZOLOTTO R, SASKA P, SCHWERK A, SERRANO J, SZYSZKO J, TABOADA A, TURIN H, VENN S, VERMEULEN R, ZETTO T 2011 Forty years of carabid beetle research in Europe - from taxonomy, biology, ecology and population studies to bioindication, habitat assessment and conservation. Zookeys: 55-148

22. KOIVULA M J 2011 Useful model organisms, indicators, or both? Ground beetles (Coleoptera, Carabidae) reflecting environmental conditions. Zookeys 100: 287-317

http://dx.doi.org/10.3897/zookeys.100.1533 
23. BRANDMAYR P, GIORGI F, CASALE A, COLOMBETTA G, MARIOTTI L, TAGLIANTI A V, WEBER F, PIZZOLOTTO R 2013 Hypogean carabid beetles as indicators of global warming? Environmental Research Letters 8: 044047

24. PIZZOLOTTO R 2009 Characterization of different habitats on the basis of the species traits and eco-field approach. Acta Oecologica 35: 142-148 http://dx.doi.org/10.1016/j.actao.2008.09.004

25. COLE L J, BROCKLEHURST S, MCCRACKEN D I, HARRISON W, ROBERTSON D 2012 Riparian field margins: their potential to enhance biodiversity in intensively managed grasslands. Insect Conservation and Diversity 5: 86-94

26. HOMBURG K, SCHULDT A, DREES C, ASSMANN T 2013 Broad-scale geographic patterns in body size and hind wing development of western Palaearctic carabid beetles (Coleoptera: Carabidae). Ecography 36: 166-177 http://dx.doi.org/10.1111/j.1600-0587.2012.07488.x

27. MAVEETY S A, BROWNE R A, ERWIN T L 2011 Carabidae diversity along an altitudinal gradient in a Peruvian cloud forest (Coleoptera). Zookeys 147: 651-66 http://dx.doi.org/10.3897/zookeys.147.2047

28. YU X-D, LÜ L, LUO T-H, ZHOU H-Z 2013 Elevational gradient in species richness pattern of epigaeic beetles and underlying mechanisms at east slope of Balang Mountain in southwestern China. PLoS One 8: e69177 http://dx.doi.org/10.1371/journal.pone.0069177

29. PIZZOLOTTO R, GOBBI M, BRANDMAYR P 2014 Changes in ground beetle assemblages above and below the treeline of the Dolomites after almost 30 years (1980/2009). Ecol Evol 4: 1284-94 http://dx.doi.org/10.1002/ece3.927

30. LOMOLINO M 2001 Elevation gradients of species-density: historical and prospective views. Global Ecology and Biogeography 10: 3-13 http://dx.doi.org/10.1046/j.1466-822x.2001.00229.x

31. SERGIO F, PEDRINI P 2007 Biodiversity gradients in the Alps: the overriding importance of elevation. Biodiversity and Conservation 16: 3243-3254 http://dx.doi.org/10.1007/s10531-006-9113-y

32. BRANDMAYR P, ZETTO BRANDMAYR T 1988 Comunità a coleotteri carabidi delle Dolomiti Sudorientali e delle Prealpi Carniche [Ground beetle comunities of southeastern Dolomites and Carnic Alps] english abstract. Studi Trentini di Scienze Naturali: Acta Biologica 64: 125-250

33. PIGNATTI-WIKUS E, PIGNATTI S 1988 Introduzione al paesaggio vegetale delle Dolomiti [Introduction to the vegetation of the Dolomites] english abstract. Studi Trentini di Scienze Naturali, Acta Biologica 64: 13-26

34. BOITI I, BOITI S T 1988 Caratterizzazione fitosociologica, pedologica e climatica di alcuni ambienti della Val di Fiemme e delle Pale di San Martino (Dolomiti) [Phytosociological characterisation, soil and climate features of some environments of the Fiemme Valley and of Pale di S. Martino (Dolomites)] english abstract. Studi Trentini di Scienze Naturali. Acta Biologica 64: 27-85

35. BRANDMAYR P, ZETTO T, PIZZOLOTTO R 2005. I Coleotteri Carabidi per la valutazione ambientale e la conservazione della biodiversità [Carabid Beetles for environmental assessment and biodiversity conservation. A Primer]. APAT, Manuale operativo 34/2005, Roma, p 240

36. DEN BOER P 1970 On the significance of dispersal power for populations of carabid-beetles (Coleoptera, Carabidae). Oecologia 4: 1-28 http://dx.doi.org/10.1007/BF00390612

37. BRANDMAYR P. 1991. The reduction of metathoracic alae and dispersal power of carabid beetles along the evolutionary pathway into the mountains. In: Lanzavecchia G, Valvassori R (eds) Selected Symposia and Monographs U.Z.I. Mucchi, Modena, p 363378

38. PIZZOLOTTO R 1994 Ground beetles (Coleoptera, Carabidae) as tool for environmental management: a geographical information system based on Carabids and vegetation for the Karst near Trieste (Italy). In: Desender K, Dufrêne M, Loreau M, Luff M L, Maelfait J-P (eds) Carabid Beetles: Ecology and Evolution. Kluwer Academic Publishers, Dordrecht, p 343-351 http://dx.doi.org/10.1007/978-94-017-0968-2_52

39. KIRKPATRICK M, BARTON N H 1997 Evolution of a species range. Am Nat 150: 1-23 http://dx.doi.org/10.1086/286054

40. FINLAYSON C 2005 Biogeography and evolution of the genus Homo. Trends in Ecology \& Evolution 20: 457-463 http://dx.doi.org/10.1016/j.tree.2005.05.019

41. COSTA G C, WOLFE C, SHEPARD D B, CALDWELL J P, VITT L J 2008 Detecting the influence of climatic variables on species distributions: a test using GIS niche-based models along a steep longitudinal environmental gradient. Journal of Biogeography 35: 637-646

42. PUNYASENA S W, ESHEL G, MCELWAIN J C 2008 The influence of climate on the spatial patterning of Neotropical plant families. Journal of Biogeography 35: 117-130

43. PIZZOLOTTO R, BRANDMAYR P 2014 IBP': A New Index to Estimate Biogeographical Peculiarity. ISRN Ecology 2014: 1-9 http://dx.doi.org/10.1155/2014/198707

44. ROSSI J P 2011 rich: an R package to analyse species richness. Diversity 3: 112-120 http://dx.doi.org/10.3390/d3010112

45. PIZZOLOTTO R 1993 Carabid beetle (Coleoptera, Carabidae) coenoses for evaluation of faunal resources and impact assessment in the Aspromonte National Park of Calabria (Italy). Coenoses 8 69-69

46. R Core team 2015. R: A language and environment for statistical computing. R Foundation for Statistical Computing, Vienna. URL: http://www.R-project.org.

47. PIELOU EC 1984 The interpretation of ecological data: a primer on classification and ordination. Wiley-Interscience, New York, p 263

48. MCGARIGAL K, LANDGUTH E, STAFFORD S (2013) Multivariate statistics for wildlife and ecology research. Springer-Verlag, Berlin, p 283

49. CHEMINI C, PIZZOLOTTO R 1990 Comunita di carabidi in siti forestali dei Monti Lessini (Trentino)(Coleoptera: Carabidae) [Carabid communities in woodland sites from the Lessini Mountains, Trentino, Italian Alps] english abstract. Studi trentini di scienze naturali. Acta Biologica 67: 197-227

50. LÉ S, JOSSE J, HUSSON F 2008 FactoMineR: an R package for multivariate analysis. Journal of statistical software 25: 1-18 http://dx.doi.org/10.18637/jss.v025.i01

51. MCCAIN C M, GRYTNES J 2010 Elevational Gradients in Species Richness. In: Encyclopedia of Life Sciences (ELS). John Wiley $\&$ Sons, Ltd, Chichester,

http://dx.doi.org/10.1002/9780470015902.a0022548

52. BRANDMAYR P, PIZZOLOTTO R. SCALERCIO S. ALGIERI M., ZETTO T 2003 Diversity patterns of carabids in the Alps and the Apennines. In: Nagy L, Grabherr G, Körner Ch, Thompson D B A (eds) Alpine Biodiversity in Europe. Springer-Verlag, Berlin, p 307-317

53. ASSMANN T 1999 The ground beetle fauna of ancient and recent woodlands in the lowlands of north-west Germany (Coleoptera, Carabidae). Biodiversity Conserv. 8: 1499-1517 http://dx.doi.org/10.1023/A:1008974413376

54. RIBERA I, DOLÉDEC S, DOWNIE I S, FOSTER G N 2001 Effect of land disturbance and stress on species traits of ground beetle assemblages. Ecology 82: 1112-1129 http://dx.doi.org/10.1890/ 0012-9658(2001)082[1112:EOLDAS]2.0.CO;2

55. JELASKA L S, DURBESIC P 2009 Comparison of the body size and wing form of carabid species (Coleoptera: Carabidae) between 
isolated and continuous forest habitats. Annales de la Société entomologique de France (N.S.), 45: 327-338

56. LA GRECA M 1955 Influenza delle variazioni climatiche del Quaternario sul popolamento entomologico d'alta montagna [Influence of climatic changes in the Quaternary on entomological populations in high mountain]. Italian Journal of Zoology 22: 489-562 http://dx.doi.org/10.1080/11250005509439217

57. BRANDMAYR P. 1979. Cenni ecologico-biogeografici sulla fauna ad invertebrati del massiccio del Monte Cavallo [Ecological and biogeographic hints on the invertebrate fauna of the Monte Cavallo massif]. Proceedings of II Convegno Studi sul territorio della Provincia di Pordenone: 145-156

58. HOLDHAUS K.: (1954) Die Spuren der Eisenzeit in der Tierwelt Europas. Universitatsverlag Wagner, Innsbruck, p 493

59. DREES C, MATERN A, VON OHEIMB G, REIMANN T, ASSMANN T 2010 Multiple Glacial Refuges of Unwinged Ground Beetles in Europe: Molecular Data Support Classical Phylogeographic Models. In Habel J C, Assmann T (eds) Relict Species. Springer, Berlin Heidelberg, p 199-215 http://dx.doi.org/10.1007/978-3-540-92160-8_11

60. BRANDMAYR P, PIZZOLOTTO R 1989 Aspetti zoocenotici e biogeografici dei popolamenti a Coleotteri Carabidi nella fascia alpina delle Vette di Feltre (Belluno) [Biogeographic and zoocoenotic aspects of the Carabid communities in the alpine belt of the Vette di Feltre (Belluno)] english abstract. Biogeographia (ns) 13: 713-743

61. MARCUZZI G 1955 Ecologia della fauna di montagna [Ecology of the mountain fauna]. Italian Journal of Zoology 22: 423-488 http://dx.doi.org/10.1080/11250005509439216
62. BRANDMAYR, ZETTO BRANDMAYR T 1986 Phenology of ground beetles and its ecological significance in some of the main habitat types of southern Europe. In: den Boer P J, Luff M L, Mossakowski D, Weber W (eds) Carabid Beetles, their adaptations and dynamics. Gustav Fischer, Stuttgart, New York, p 195-220.

63. WEBER F, HEIMBACH U 2001 Behavioural, reproductive and developmental seasonality in Carabus auronitens and Carabus nemoralis (Col., Carabidae). Mitteilungen aus der Biologischen Bundesanstalt für Land und Forstwirtschaft. Berlin-Dahlem, Germany, Berlin, p 194

64. BAUMGARTNER R, PRIGGE M, HEIMBACH U, WEBER F 2005 The Dynamics of a Carabus auronitens Population Subject to a Powerful Abiotic Key Factor. Biologische Bundesanstalt für Land und Forstwirtschaft, Berlin, p 112

65. HORÁK J, VODKA Š, PAVLÍČEK J, BOŽA P 2013 Unexpected visitors: flightless beetles in window traps. Journal of insect conservation 17: 441-449 http://dx.doi.org/10.1007/s10841-012-9526-8

66. DRAY S, LEGENDRE P 2008 Testing the species traits-environment relationships: the fourth-corner problem revisited. Ecology 89: 3400-3412 http://dx.doi.org/10.1890/08-0349.1

67. BUTTERFIELD J 1996 Carabid life-cycle strategies and climate change: a study on an altitude transect. Ecological Entomology 21: 9-16 http://dx.doi.org/10.1111/j.1365-2311.1996.tb00260.x

68. SOMME L 1993 Living in the cold. Biologist 40: 14-17

69. HODKINSON I D, WEBB N, BALE J, BLOCK W, COULSON S, STRATHDEE A 1998 Global change and Arctic ecosystems: conclusions and predictions from experiments with terrestrial invertebrates on Spitsbergen. Arctic and Alpine Research 30: 306-313 
Appendix Table. List of the sampled species their scientific names and authorities. Columns are as follows „wings": $b=$ brachypterous, $m=m a c-$ ropterous, $d$ = dimorphic; "choro. “i.e. chorology: $I=$ Regional endemic species, $I I=$ Central-montane European species, $I I I=$ European species, $I V=$ Euro-Asiatic, Euro-Siberian species, $V=$ Palaearctic, Holoarctic, Circumpolar species; "diet“: $z$ spc = zoophagous specialised (e.g. helicophagy, collembola), $z=$ zoophagous, $z f=$ an opportunistic diet feeding also on seeds ( $z f$ ); "rit. “i.e., reproductive rhythm: $s=$ spring breeders, $a=$ autumn breeders, $2 y=$ two-year breeders. In the bottom lines the number of species for each species-traits has been computed.

\begin{tabular}{|c|c|c|c|c|}
\hline wings & coro. & diet & rit. & \\
\hline $\mathrm{b}$ & III & $\mathrm{z}$ & $\mathrm{a}$ & Abax (Abax) pilleri Csiki 1916 \\
\hline $\mathrm{b}$ & I & $\mathrm{z} \mathrm{spc}$ & & Abax (Abax) parallelepipedus (Piller \& Mitterpacher 1783) \\
\hline $\mathrm{b}$ & I & $\mathrm{zf}$ & a & Amara (Leirides) alpestris A. Villa \& G.B. Villa 1833 \\
\hline $\mathrm{m}$ & $\mathrm{V}$ & zf & $s$ & Amara (Celia) erratica (Duftschmid 1812) \\
\hline $\mathrm{m}$ & IV & zf & $s$ & Amara (Amara) lunicollis Schiodte 1837 \\
\hline $\mathrm{m}$ & IV & zf & a & Amara (Celia) praetermissa (C.R. Sahlberg 1827) \\
\hline $\mathrm{m}$ & $\mathrm{V}$ & zf & & Amara (Paracelia) quenseli (Schonherr 1806) \\
\hline $\mathrm{m}$ & $\mathrm{V}$ & $\mathrm{z}$ & $s$ & Princidium (Testedium) bipunctatum (Linne 1761) \\
\hline $\mathrm{m}$ & II & $\mathrm{z}$ & $s$ & Ocydromus (Testediolum) glacialis (Heer 1837) \\
\hline $\mathrm{m}$ & III & $\mathrm{z}$ & $s$ & Ocydromus (Ocyturanes) incognitus (G. Muller 1931) \\
\hline $\mathrm{d}$ & $\mathrm{V}$ & $\mathrm{z}$ & $s$ & Metallina (Metallina) lampros (Herbst 1784) \\
\hline $\mathrm{d}$ & IV & $\mathrm{z}$ & a & Calathus (Neocalathus) melanocephalus (Linne 1758) \\
\hline b & $\mathrm{V}$ & $\mathrm{z}$ & a & Calathus (Neocalathus) micropterus (Duftschmid 1812) \\
\hline b & III & $\mathrm{z}$ & $s$ & Carabus (Chrysocarabus) auronitens Fabricius 1792 \\
\hline b & I & $\mathrm{z}$ & a & Carabus (Orinocarabus) bertolinii Kraatz 1878 \\
\hline b & IV & $\mathrm{z}$ & $s$ & Carabus (Tomocarabus) convexus Fabricius 1775 \\
\hline b & I & $\mathrm{z} \mathrm{spc}$ & $s$ & Carabus (Platycarabus) creutzeri Fabricius 1801 \\
\hline b & IV & $\mathrm{z}$ & a & Carabus (Megodontus) germarii Sturm 1815 \\
\hline b & III & $\mathrm{z}$ & a & Carabus (Oreocarabus) hortensis Linne 1758 \\
\hline b & II & $\mathrm{z}$ & a & Carabus (Orinocarabus) linnaei Panzer 1812 \\
\hline $\mathrm{m}$ & III & $\mathrm{z}$ & s & Clivina (Clivina) fossor (Linne 1758) \\
\hline b & II & $\mathrm{z} \mathrm{spc}$ & $\mathrm{a}$ & Cychrus angustatus Hoppe \& Hornschuch 1825 \\
\hline b & II & $\mathrm{z} \mathrm{spc}$ & $\mathrm{a}$ & Cychrus attenuatus (Fabricius 1792) \\
\hline b & III & $\mathrm{z} \mathrm{spc}$ & a & Cychrus caraboides (Linne 1758) \\
\hline b & II & $\mathrm{z} \mathrm{spc}$ & a & Cychrus italicus Bonelli 1810 \\
\hline $\mathrm{d}$ & IV & $\mathrm{z}$ & $\mathrm{a}$ & Cymindis (Tarulus) vaporariorum (Linne 1758) \\
\hline d & IV & $\mathrm{z}$ & $s$ & Dyschiriodes (Eudyschirius) globosus (Herbst 1783) \\
\hline d & II & $\mathrm{z} \mathrm{spc}$ & a & Leistus (Leistus) nitidus (Duftschmid 1812) \\
\hline b & $\mathrm{V}$ & $\mathrm{z}$ & & Leistus (Leistus) piceus Frölich 1799 \\
\hline b & IV & $\mathrm{z}$ & $2 y$ & Molops piceus (Panzer 1793) \\
\hline b & I & $\mathrm{z}$ & a & Oreonebria (Oreonebria) diaphana (K. Daniel \& J. Daniel 1890) \\
\hline $\mathrm{m}$ & IV & $\mathrm{z}$ & $\mathrm{a}$ & Nebria (Boreonebria) rufescens rufescens (Ström 1768) \\
\hline $\mathrm{d}$ & $\mathrm{V}$ & z spc & s & Notiophilus aquaticus (Linne 1758) \\
\hline $\mathrm{d}$ & III & $\mathrm{z} \mathrm{spc}$ & s & Notiophilus biguttatus (Fabricius 1779) \\
\hline $\mathrm{m}$ & IV & $\mathrm{z}$ & $s$ & Poecilus (Poecilus) versicolor (Sturm 1824) \\
\hline b & II & $\mathrm{z}$ & $2 y$ & Pterostichus (Oreophilus) jurinei (Panzer 1803) \\
\hline b & II & $\mathrm{z}$ & $2 y$ & Pterostichus (Cheporus) burmeisteri burmeisteri Heer 1838 \\
\hline b & II & $\mathrm{z}$ & $2 y$ & Pterostichus (Oreophilus) morio (Duftschmid 1812) \\
\hline $\mathrm{m}$ & IV & $\mathrm{z}$ & $s$ & Pterostichus (Bothriopterus) oblongopunctatus (Fabricius 1787) \\
\hline b & I & $\mathrm{z}$ & $2 y$ & Pterostichus (Parapterostichus) schaschli (Marseul 1880) \\
\hline b & II & $\mathrm{z}$ & $2 y$ & Pterostichus (Haptoderus) unctulatus (Duftschmid 1812) \\
\hline b & III & $\mathrm{z}$ & $s$ & Stomis (Stomis) rostratus (Sturm in Duftschmid 1812) \\
\hline b & I & $\mathrm{z}$ & a & Trechus (Trechus) dolomitanus Jeannel 1931 \\
\hline d & III & $\mathrm{z}$ & a & Trechus (Trechus) obtusus Erichson 1837 \\
\hline b & I & & a & Trechus (Trechus) pallidulus pallidulus Ganglbauer 1891 \\
\hline d & I & zf & $2 y$ & Trichotichnus (Trichotichnus) knauthi (Ganglbauer 1901) \\
\hline d & II & zf & $2 y$ & Trichotichnus (Trichotichnus) laevicollis (Duftschmid 1812) \\
\hline
\end{tabular}




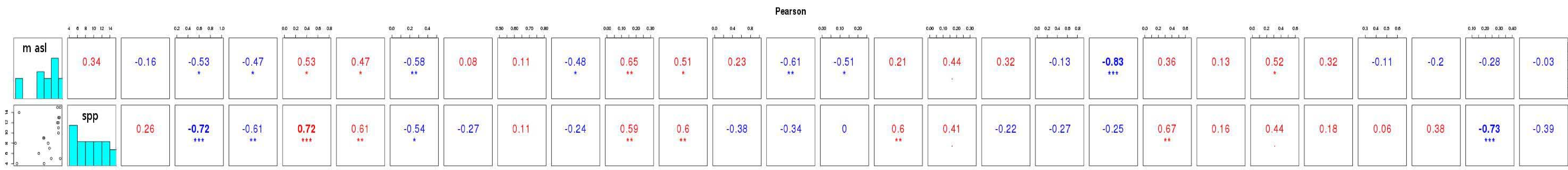

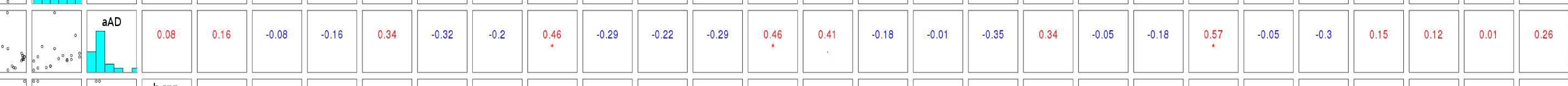

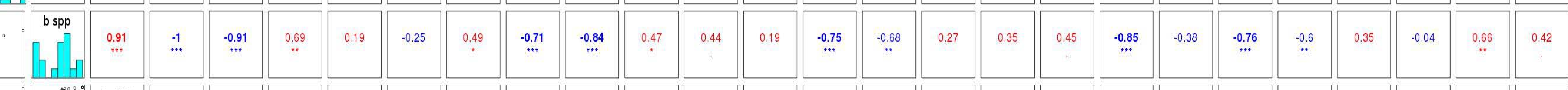

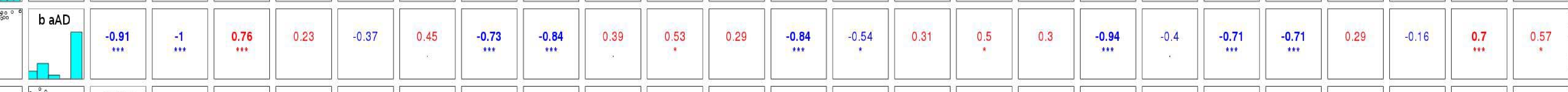

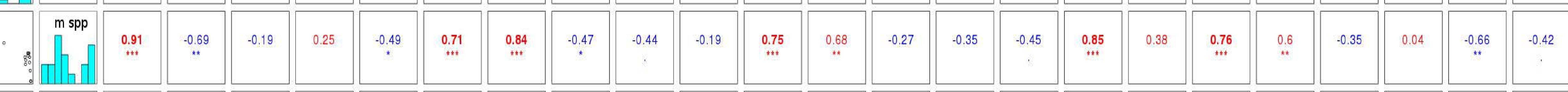

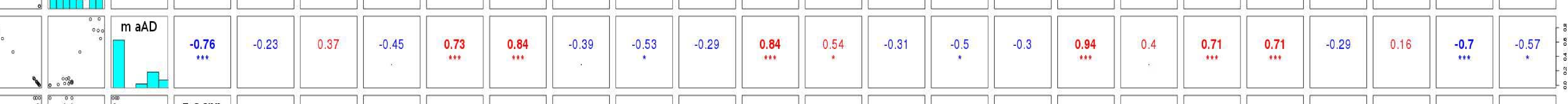

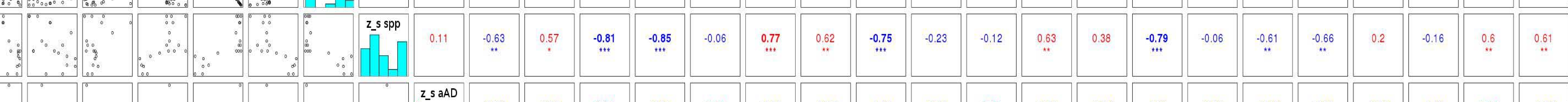

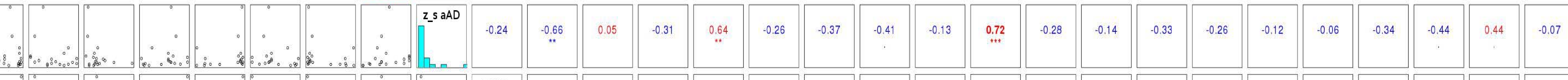

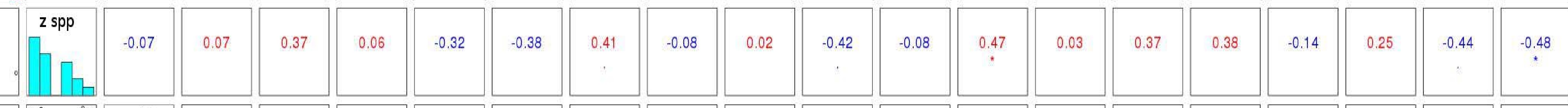

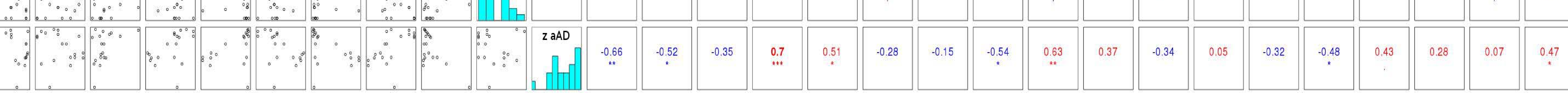

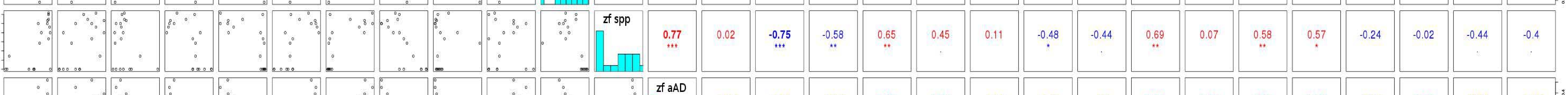

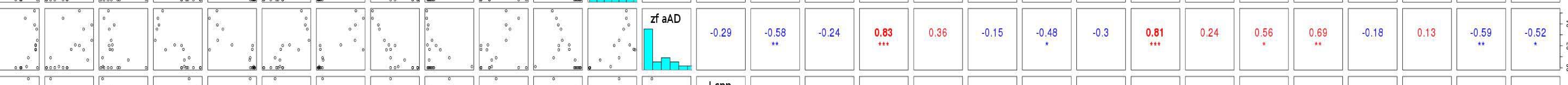

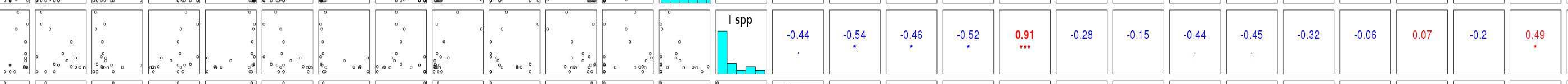
are

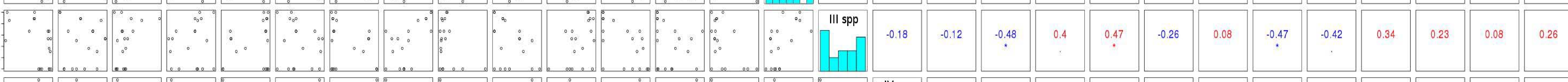

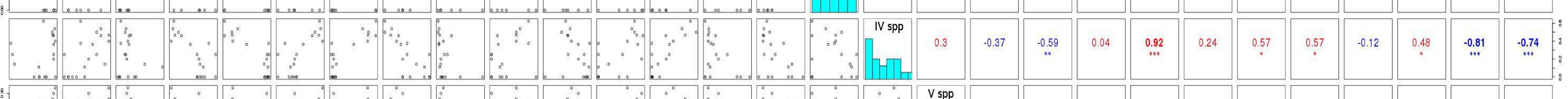

18.

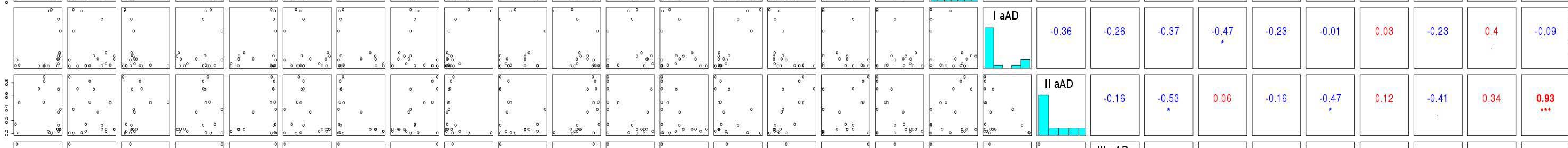

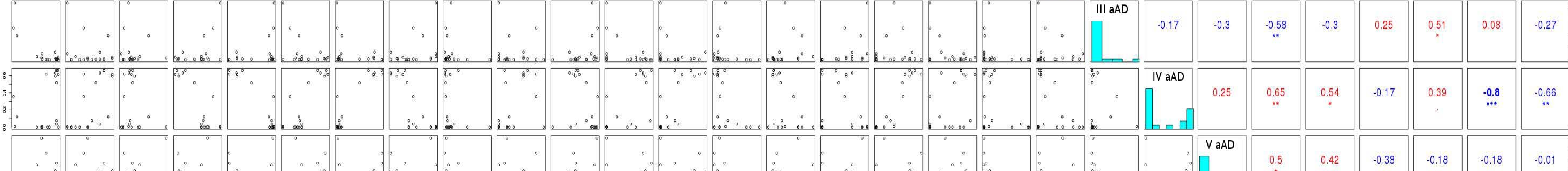
-

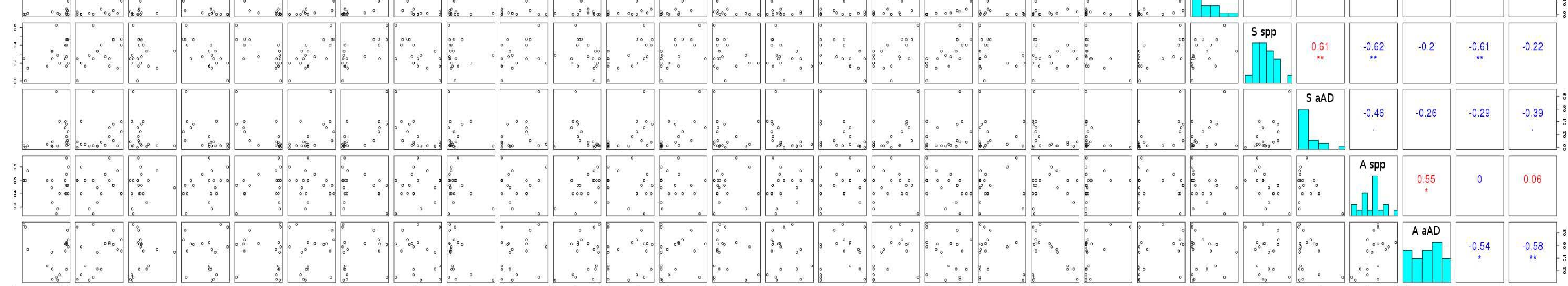

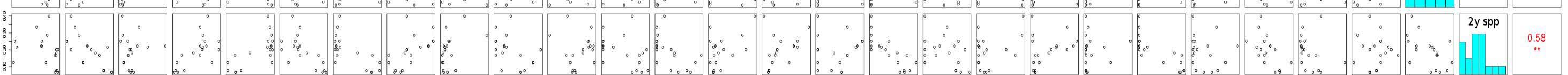

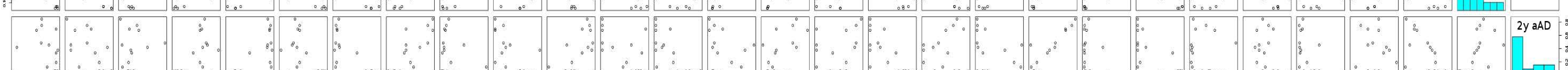

